\title{
On the Reception and Uses of Li Shizhen's Classified Materia Medica (Bencao gangmu) in $17^{\text {th }}$-century Japan: Text, Categories, Pictures ${ }^{1}$
}

\author{
Matthias HAYEK
}

\section{Introduction}

The Bencao gangmu 本草綱目 (Classified Materia Medica, Jp. Honzō kōmoku), a summa on pharmacology (bencao 本草, Jp. honzo) published in 1596 in Nanjing, has been praised as a truly epoch-making book. The richness of the work alone could justify its fame: it lists, describes, and discusses the medicinal properties of 1,895 different kinds of plants, herbs, minerals, and animals. Nor did its compiler, Li Shizhen 季時珍 (1518-1593), stop at merely collecting the more traditional sort of bencao material: fully endorsing the Neo-Confucian epistemological paradigm of "investigation of things" (gewu zhizhi 格物致知, Jp. kakubutsu chichi), ${ }^{2}$ he extended the purview of his compilation to the basic components of the surrounding world, as well as to the realm of man. If, as Georges Métailié has meticulously shown, Li cannot really be considered a "precursor" to modern zoology, he nevertheless devised a system that, while retaining most of the subjective categories of "folk taxonomy," still strove after a renewed form of coherency. ${ }^{3}$

${ }^{1}$ This research would not have been possible without the digital resources made available by the National Institute of Japanese Literature, both through the renewed Database of Pre-modern Japanese Works, and through the Center for Open Data in the Humanities (CODH). I would also like to thank the anonymous reviewers for their useful remarks and advice, as well as Jeffrey Knott for his careful editing. For any remaining mistakes, the fault is mine alone.

${ }^{2}$ Elmann, Benjamin, On Their Own Terms: Science in China 1550-1900 (Cambridge: Harvard University Press, 2005).

${ }^{3}$ See the following series of studies by George Métailié: (1) "Des mots et des plantes (dans le Bencao gangmu de Li Shizhen)", Extrême-Orient/Extrême-Occident 10 (1988), pp. 27-43; (2) "The Bencao gangmu (Classified Materia Medica) of Li Shizhen-An innovation in Natural History?", in Innovation in Chinese Medicine, ed. Elisabeth Hsu (Cambridge: Cambridge University Press, 2001); (3) "Le Bencao gangmu de Li Shizhen et l'histoire naturelle au Japon durant la période d'Edo (1600-1868)", Études chinoises 25 (2006), pp. 41-68 and pp. 221-261; and (4) "Some Reflections on the History of Botanical Knowledge in China”, Circumscribere 3 (2007), pp. 66-84. 
The broad scope of Li's work may explain why it enjoyed a wide reception not only in China but also in other parts of East Asia. In the Japanese case, the introduction of the Bencao gangmu in the first years of the $17^{\text {th }}$ century has been defined as the key event that laid the foundations for further developments, not only in the pragmatic realm of pharmacology proper (bon oggaku本草学 or yakubutsugaku 薬物学), but also in what might be called the "study of nature" in its broader sense (bakubutsugaku 博物学). According to Ueno Masuzō 上野益三 (1900-1989), one of the chief specialists on the history of the natural sciences in Japan, the broader, naturalistic scope of Li's book stimulated several successive generations of Japanese scholars, leading to the formation of a local tradition of natural history. ${ }^{4}$ This tradition is seen as clearly distinct from the Chinese one, insofar as for these scholars, the main interest lay in listing and in reflecting upon local specimens, and additionally because, independently as a local tradition, it proved able to coexist with — and at some point even to converge withthose Western "scientific" views that were gradually being introduced to Japan through the so-called field of "Dutch studies" (rangaku 蘭学). Within this narrative, which had already become established by the time of Shirai Mitsutarō 白井光太郎 (1863-1932) and Watanabe Kōzō 渡辺幸三 (1905-1966)—Ueno’s forerunners in the field of the history of bonzo and bakubutsugaku in China and Japan-Li's Bencao gangmu played an ambiguous role. On the one hand, it was seen as having been a welcome catalyst for the development of a local scholarship. On the other, it was cast as a "limitation" partly responsible for preventing the earlier appearance of a properly scientific mode of thought, whether in spontaneous generation domestically or through the external stimulus of Western knowledge. ${ }^{5}$ In the words of Watanabe and Ueno, the Bencao ended up "dominating" (shibai 支配) ${ }^{6}$ the mind of Japanese naturalists, who tended to "blindly follow" Li's system, and were consequently as stubbornly impervious to change as Aristotelians had been in the face of Copernicus, Galileo, and the Kepler findings. In these scholars" "progressivist" view—reminiscent of what Lucien Febvre called in European context the "old myth of the Renaissance" — Kaibara Ekiken's 貝原益軒 (1630-1714) work Yamato hon₹o 大和本草 (Japanese Materia Medica, 1708) represents, at long last, a form of "critical emancipation" from the Bencao gangmu. Having thus been launched, moreover, this movement was in turn nourished and sustained, so the narrative goes, by an empiricist stance that emphasized

\footnotetext{
${ }^{4}$ Ueno Masuzō 上野益三, “Honzō kōmoku to Nihon no hakubutsugaku” 本草綱目と日本の 博物学, Könan joshi daigaku kenkyū kiyō 甲南女子大学研究紀要 7 (1971), pp. 153-163.

${ }^{5}$ Watanabe Kōzō 渡辺幸三, “Tokugawa jidai ni okeru honzōgaku gairon” 徳川時代に於ける 本草学概論, Yakuyō shokubutsu to shōyaku薬用植物と生薬 3 (1950), pp. 33-39.

${ }^{6}$ Ibid., p. 36.

${ }^{7}$ Ueno (op. cit.), p. 154.

${ }^{8}$ Febvre, Lucien, Le problème de l'incroyance au 16ème siècle: la religion de Rabelais (Paris: Albin-Michel, 1942), p. 353.
} 
working with actual samples as being more important than any search for overarching, arbitrary theories — an approach that would indeed be followed by later naturalists such as Ono Ranzan 小野蘭山 (1729-1810). Recent studies on this topic have helped bring both depth and nuance to this narrative, ${ }^{9}$ in which one might even perceive an attempt to justify a form of "Japanese cultural exception" within the East Asian sphere, one that not only explains Japan's success in rapid modernization (Japanese early-modern scholarship ostensibly being already almost on par with Western science), but also accounts for its failures (hindered, ostensibly, from "reaching" the level of the West earlier by virtue of its age-old reliance on Chinese paradigms). In the end, however, the idea that the Bencao ruled the field from its "official" introduction in 1607 up until 1709 appears to remain unchallenged. One of the main reasons, as I see it, for the persistence of this view, is that the original observations leading to its formulation still stand on strong ground. The fact remains that Li's Bencao was reprinted 14 times in Japan over the course of the Edo period (1603-1868), and its influence was indeed very palpable, on subsequent publications treating materia medica and on encyclopedic works alike. Yet the question of the exact nature of this influence, especially beyond the boundaries of pharmacology proper, has so far gathered little attention, at least outside of studies dedicated to the particular textual landmarks of the aforementioned narrative. In this paper, I hope to give a closer look at how the Bencao was actually used, in a selection of works published before 1700 . After first briefly reviewing the details of the Bencao's own composition and the earliest traces of its introduction in Japan, I will move on to consider its direct influence on Japanese materia medica texts, as well as on materia dietetica texts, a genre closely related to the field of hon₹ō. Finally, I will turn to the illustrated dictionaries and commentaries that made use of the Bencao.

The "details" of the Bencao gangmu can be narrowed down to two main aspects: (1) its formal structure, e.g., the general organization of the text, the structure of each entry, etc., and (2) the knowledge it contains-that is, the choices, selections, and quotations produced by Li himself, as well as all the pictures added in by the work's various publishers. My goal here is to shed light on which of these aspects has been influential, depending on the genre of publication. Contrary to what a situation of epistemic "domination" might lead one to expect, it seems to me that Li's theoretical framework, and the worldview he tried to construct in his magnum opus, were not necessarily received in their fullness before the time of the so-called “critical” scholars such as Inō Jakusui 稲生若水 (16551715) and Kaibara Ekiken. Rather, the work functioned mostly as a collection of textual and pictorial elements that were used to supplement a preexisting framework,

\footnotetext{
${ }^{9}$ Isono Naohide 磯野直秀, “Nihon hakubutsugaku-shi oboegaki 14” 日本博物学史覚書 XIV, Keiō gijuku daigaku Hiyoshi kiyo 慶應義塾大学日吉紀要 44 (2008), pp. 99-124. See also Métailié, op. cit. (2006), as well as Federico Marcon, The Knowledge of Nature and the Nature of Knowledge in Early Modern Japan (Chicago: University of Chicago Press, 2015).
} 
one being rediscovered from local classics amidst the boom in commercial publishing. In other words, reception of the Bencao as a coherent whole, reception that could serve as a basis for further development along the same lines as Li's work and following a similar methodology, may have occurred much later than the traditional narrative would have us believe.

\section{The Bencao gangmu: Publication History, Structure, and Contents}

Li Shizhen finished his compilation in 52 juan 巻 (volumes), after 30 years of work, in 1578. It was printed eighteen years later, in 1596, in Jinling 金陵 (modern Nanjing), after Li's death. This "Jinling" edition, the first of three that were produced before the end of the $17^{\text {th }}$ century, adds two separate fascicles containing illustrations for the sections on minerals, plants, and animals. ${ }^{10} \mathrm{Li}$ Shizhen probably had no part in these pictures, which were devised by his two sons, Li Jianzhong 李建中 and Li Jianyuan 李建元, and which are famous for their lack of both quality and naturalistic accuracy. A new edition, known as the Jiangxi 江西 edition, was made in Nanchang 南昌 in 1603, with again the same illustrations, printed either as a separate fascicle, or, in subsequent copies, placed as appropriate at the beginning of each volume. It was only in 1640 — with the new printing by Qian Weiqi 銭蔚起 in Wulin 武林 (Hangzhou 杭州), known as the Wulin or Qianya 銭衛 edition- that the illustrations were redrawn and, in some cases, amended. This last edition became the basis for all later reprintings, until a wholly new edition was produced in 1885 .

The 52 juan are organized by category as follows:

$\begin{array}{lr}\text { Water section } & 1 \\ \text { Fire section } & 1 \\ \text { Earth section } & 1 \\ \text { Metals and minerals section } & 5 \\ \text { Herbs section } & 10 \\ \text { Grains section } & 4 \\ \text { Vegetables section } & 10 \\ \text { Fruits section } & 4 \\ \text { Trees section } & 6 \\ \text { Clothes and utensils section } & 6 \\ \text { Insects and vermin section } & 4 \\ \text { Scaly creatures section } & 4 \\ \text { Shelled creatures section } & 2 \\ \text { Birds section } & 4 \\ \text { Beasts section } & 4 \\ \text { Man section } & 1\end{array}$

\footnotetext{
${ }^{10}$ On the various editions of the Bencao, see Watanabe Kōzō, "Ri Jichin no Honzō kōmoku to sono hanpon” 李時珍の本草綱目とその版本, Tojyōshi kenkyu 東洋史研究 12-4 (1953), pp. 333357.
} 
Through this general structure, we can see that $\mathrm{Li}$ tried to innovate in a number of ways. ${ }^{11}$ Division of the materia medica into natural categories was not new in itself: this had been the standard model in the field since Tao Hongjing's 陶弘景 Shennong bencao jing jizhu 神農本草経集註 (Collected Commentaries on Shennong's Materia Medica), compiled at the end of the $6^{\text {th }}$ century CE. However, the number of such sections did not show much change until the $15^{\text {th }}$ century, and works published in Li Shizhen's own time did not have more than 10 categories. ${ }^{12} \mathrm{Li}$ had thus greatly augmented the number of categories, deriving some of them by division-he separated scaly and shelled things_- while others, such as the initial ones dealing with natural elements, or the later one on clothes, he simply added, taking his inspiration from encyclopedic works (leishu 類書). What is more, he made notable changes to the order of the sections, which he justifies as follows in his fanli 凡例 (preliminary remarks):

旧本玉石水土混同、諸虫鱗介不別、或虫入木部、或木入草部。今各列為部、 首以水火、次之以土、水火為万物之先、土為万物母也。次之以金石、従土 也。次之以草穀菜果木、従微至巨也。次之以服器、従草木也。次之以虫鱗介 禽獸、終之以人、従賎至貴也。 ${ }^{13}$

Old books mix up jades, minerals, waters, and earths, they do not distinguish between insects, scaly creatures, and shelled creatures; some "insects" have an entry in the tree section and some trees in the herb section... I have now ordered everything into sections $(b u)$ beginning with waters and fires, followed by earths. [That is because] Water and Fire come before the myriad things, and Earth is their mother. Then [follow] the metals and minerals, [because] they come from the Earth; then the herbs, grains, vegetables, fruits, and trees, from the smallest to the biggest; then the clothes and utensils, [made] from herbs and trees; then the "insects," the scaly creatures, the shelled creatures, the birds, the beasts, to finish with man: from the vile to the precious. ${ }^{14}$

In other words, what Li had created was a wholly new "ladder of things," with a hierarchy more coherent and more clearly-formulated than anything found in previous encyclopedias. ${ }^{15} \mathrm{He}$ also abandoned the traditional ranking in order by

\footnotetext{
${ }^{11}$ For an extensive presentation of the contents and structure of the Bencao gangmu, see Paul Unschuld, Medicine in China: A History of Pharmacentics (Berkeley: University of California Press, 1986), pp. 145-163. See also Marcon (op. cit.), pp. 35-37.

${ }^{12}$ Métailié, op. cit. (2001), p. 225.

${ }^{13}$ Li Shizhen 李時珍, Bencao gangmu 本草綱目 (pub. 万暦 Wanli 18/1590), vol. 3. Available at: https://dl.ndl.go.jp/info:ndlip/pid/1287084/3

${ }^{14}$ Métailié, op. cit. (2001), p. 227.

${ }^{15}$ On the conceptual framework behind Li's design, see Carla Nappi, The Monkey and the Inkpot: Natural History and its Transformations in Early Modern China (Cambridge: Harvard University Press, 2010). On the role of order in encyclopedias, see Matthias Hayek, "Encyclopaedia and Dictionaries in Premodern and Early Modern Japan: Chinese Heritage and the Local Reordering of Knowledge," to be published in a forthcoming volume on cultural encyclopedias edited by Anna Boroffka.
} 
the so-called “three grades" (Ch. sanpin 三品), which grouped drug materials according to their level of toxicity (superior $=$ non-toxic, intermediate $=$ moderately toxic, low $=$ toxic), replacing this instead with a new hierarchy that reflected the relative subordination of each classificatory level to another. According to Li's fanli, "Sections" ( $b u$ 部), such as "herbs" or "fish," represent thus a higher tier of more encompassing gang 綱 (Jp. ko), while "Categories" (lei 類, Jp. rui) such as "fragrant tree" or "scaly fish" or "mountain birds" constitute, relative to the gang, a lower tier of more narrowly-drawn mu 目 (Jp. moku). And these "Categories" (lei), in their own turn, become themselves gang with respect to the yet narrower mu of more specific "kinds" (zhong 種, Jp. shu). This same hierarchy is also applied within the individual entries, where the first section, devoted to the principle of "rectification of names" (₹hengming 正名), is a gang when compared to the alternative names given in following sections. Finally, although the preliminary remarks never state this explicitly, there are what Georges Métailié calls "covert categories" that delineate series of what might seem to be considered "families" of entries, ${ }^{16}$ with their own hierarchies divided between one particular generic entry and others which, in a few cases, are explicitly introduced as its "subordinates" (shu属, Jp. zoku). ${ }^{17}$ For example, the prunus mume (mei 梅) is a sort of "subkind" of prunus salicinia ( $l i$ 李). These families, as well as this notion of "shu" itself, Li Shizhen seems to have found in the Erya 爾雅, one of the oldest leishu (dating to the Han dynasty), as well as in that work's commentaries, such as those by Guo Pu 郭璞 (276-324) or Luo Yuan 羅願 (1136-1184). The criteria behind these ancient "families" are not always clear. However, in many cases, they proceed from similarities in forms and habits, affinities which are sometimes also underlined by a semantic proximity, e.g., the use of the same character in a compound name. ${ }^{18}$

As for the entries themselves, they follow a fixed pattern, with up to eleven sections, but in most cases usually only four: (1) the shiming 釈名 (explanation of names), that is, the determination of the "correct name," usually by looking at ancient sources such as the Erya, then (2) the jijie 集解 (collected commentaries), (3) the qiwei 気味 (quality and flavor), and (4) the zhu₹bi 主治 (main therapeutic indications). And if these last two are indeed quite common in bencao literature, $\mathrm{Li}$ also devised new headings of his own, adding the faming 発明 (explication) section, where he gives details on how and why various drugs are effective, providing either his own interpretation or quoting those of other authors, and also adding the fulu 附録 (appendix) section, where one can find new additions of

\footnotetext{
${ }^{16}$ Métailié, op. cit.. (2007), p. 71.

${ }^{17}$ The term $s h u$ 属 is also used to specify the grouping under which a given material is "subordinated" within various larger organizational schemata, such as the five phases, the yin and yang, or, in the case of body parts, the set of governing organs, in order to indicate the particular broader category with which the "subordinate" shares correlative properties.

${ }^{18}$ For a detailed presentation of the general structure of the Bencao gangmu, see Nappi (op. cit.), pp. 50-68.
} 
materials or kinds that are in some manner related to the main entry, without being singled out yet as sub-species in their own right, or whose therapeutic usages had yet to become widely recognized and known. ${ }^{19}$

All these innovations indicate a theoretical and systematic intent on Li's part. Even though his groupings, whose criteria alternate between philological, morphological, and ecological proximity, are quite different from those of modern "scientific" taxonomy, his work has a strong internal coherency, deeply rooted in Neo-Confucian natural philosophy and its gewu 格物 worldview. This novelty in its structure and in its aims, in other words, thus characterizes the Bencao gangmu no less than any of its extended pharmacological content.

The question is: to what extent was Li's intent actually received in $17^{\text {th }}$-century Japan?

\section{Early Reception in Japan}

Turning now to the introduction of the Bencao gangmu in Japan, we can see that it followed two main lines, which together would end up defining the subsequent development of its influence: (1) the medicinal and the dietetical line, and (2) the so-called “encyclopedic" line. The latter begins with Hayashi Dōshun 林道春 (1583-1657), better known as Razan 羅山, who recorded Li's work in his Kiken shomoku 既見書目 (Catalogue of Books Already Seen) as early as 1604. Three years later, in 1607, Razan obtained an exemplar of the Jianxi edition in Nagasaki, which he presented to Tokugawa Ieyasu 徳川家康 (1543-1616). Meanwhile, there is evidence attesting to the fact that the Bencao was also known within the Manase 曲直瀬 school of medicine. Manase Gensaku 曲直瀬玄朔 (1549-1632), adopted son of the school's founder, Manase Dōsan 曲直瀬道三 (1507-1594), and heir also to the school's headship, published in 1608 a pharmacology manual, Yakushō nōdoku 薬性能毒 (On the Potential Effects of Drugs), based largely on Dōsan's own Nōdoku 能毒 (Potential Effects) but also expanded with contents from the Bencao. ${ }^{20}$

Razan was the first to give an overview of the work's general content and structure, with his Tashikiben 多識編 (Book of Extensive Knowledge). This is

\footnotetext{
${ }^{19}$ On the structure of these entries, see Métailié, op. cit. (2001), and Nappi (op. cit.).

${ }^{20}$ Other students of the same school mention the Bencao in their writings as early as the early 1600's. See Marcon (op. cit.), pp. 57-58. On the Manase school, see Machi Senjurō 町泉寿郎, "The Evolution of 'Learning' in Early Modern Japanese Medicine," in Listen, Copy, Read: Popular Learning in Early Modern Japan, eds. Matthias Hayek and Annick Horiuchi (Leiden: Brill, 2014), pp. 163-204. On the relationship between Dōsan's original Nōdoku, which circulated among his disciples in manuscript form, and later printed manuals, see Noguchi Daisuke 野口大輔, Endō Jirō 遠藤次郎, Nakamurua Teruko 中村輝子, Aoyagi Makoto 青柳誠, “Manase Dōsan Yakushō nōdoku no kenkyū” 曲直瀬道三『薬性能毒』の研究, Nibon ishigaku zasshi 日本医史学雑誌 53:1 (2007), pp. $150-51$.
} 
not a pharmacology treatise, but rather a glossary covering the entries of both the Bencao gangmu and Wang Zhen's 王禎 (1271-1333) agronomical encyclopedia, the Nongshu 農書 (1313). Thus, although it follows the order and structure of Li's work throughout its first four kan 巻 and at the beginning of the fifth, it then continues with words from the Nongshu. Razan's book was completed in 1612, and circulated in manuscript form before being printed in 1630 in movable type, with a subsequent woodblock edition in 1631. Its 2,315 entries share the same, uniform organization: the excerpted Chinese name is given a possible equivalent in Japanese (with the phrase ima an [zuru ni] 今案, lit. "I now suggest"), most of which are taken from Minamoto no Shitagō’s 源順 (911-983) Wamyō ruijushōo 和名類聚抄 (Classified Compilation of Japanese Names [i.e. equivalents to Chinese characters]), or Wamyōshö, compiled between 931 and 938, and first printed in 1610 in moveable type. Razan, an early advocate of Neo-Confucianism and polymath scholar, was probably sensitive to Li's gewn-oriented project. His glossary, however, limited itself to a "study of the names" (meibutsugaku 名物学), and thus exploited only the first part of each entry, the shiming, working from a lexicographical perspective. In fact, Tashikihen was mostly used in the context of Chinese poetry composition, a field quite remote from Li's own encyclopedic project. ${ }^{21}$

Conversely, the Manase school did not necessarily embrace the gewn worldview, or indeed Li's personal innovations, in its usage of the Bencao. In Shokushö nödoku 食性能毒 (On the Potential Effects of Foods), a section on the toxicity of ingredients included in the work Nichiyo shokushō 日用食性, a materia dietetica in Japanese published in 1631, Manase Gensaku, while indeed following the order of the entries of the Bencao in his selection of substances, nonetheless based his text almost exclusively on the qiwei and zhushi sections of the entries, or in other words on the most "classical" and least unique parts of Li's work, and with no explicit reference to it as source..$^{22}$ The "categories" (lei), too, are not made apparent, and as such, the gang/mu hierarchy is not clearly visible. As we will see, materia dietetica (shokumotsu hon₹ō 食物本草) constituted an important category of hon₹o-related books. In their prefaces, the authors and compilers of such works position these as practical guides for “people’s day-to-day lives” (tami no nichiy $\overline{0}$ 民の日用), leaving little place for medical theory.

Subsequently, Li's book was itself printed in Japan for the first time in 1637 by Noda Yajiemon 野田弥次右衛門. This first edition is based on the Jiangxi version. The text has glossing points (kunten 訓点) to help Japanese readers understand the text, as well as Japanese names for the entries, which are taken from Razan's Tashikiben. A new version, based on the same Jiangxi version but with

\footnotetext{
${ }^{21}$ Marcon (op. cit.), pp. 67 and 71, quoting from Nishimura Saburō 西村三郎 and Kameda Jirō 亀田次郎.

${ }^{22}$ Katō Itsuko 加藤伊都子 and Mayanagi Makoto 真柳誠, “Manase Gensaku Shokushō nōdoku ni okeru Hon rō kōmoku no shusha” 曲直瀬玄朔『食性能毒』に扮ける『本草綱目』の取捨, Nibon ishigaku zasshi 日本医史学雑誌 38:2 (1992), pp. 213-215.
} 
pictures from the 1640 Qianya edition, was printed in 1653. Finally, two editions based completely on the Qianya version were produced, one in 1659 (with a revised reprint in 1669 and many later undated editions), and one in 1672. ${ }^{23}$

Thus, by 1640, Li's work had been made more easily available to a scholarly audience, with its updated picture set and with Razan's Japanese readings. How did this new situation influence the reception of the work, and the intellectual project underlying it as a whole?

The period between the Kan'ei 寛永 (1624-1645) and Kanbun 寛文 (16611673) eras represents a turning point in the history of publishing in Japan. The 1630 's saw the rise of commercial publishers in Kyoto, such as the aforementioned Noda, who gradually shifted from moveable-type to woodblock printing, a technique that allowed the inclusion of illustrations with relative ease. And even though their numbers paled in comparison to those of Buddhist texts, which still accounted for the majority of publications, various practical manuals, too- on medicine, divination, or poetry, together with commentaries or illustrated versions of classical texts-began to occupy a significant part of the market. According to Mayanagi Makoto 真柳誠, some 58 books related to honzō were published between 1608 and 1699, almost 77\% (45) of them after 1630. ${ }^{24}$

The Bencao comes to figure more and more prominently in a greater share of these publications, at least from the 1650's onwards. In Hon 20 kanben 本草簡便 (A Simplified Materia Medica), published in 1652, Jūansai Gen'yū 就安斎玄幽, supposedly a disciple of the Manase school, lists 204 substances in all. Each of these entries starts with Gen'yū's own commentary, followed by a section discussing the name of the given material and a further section on its therapeutic properties. In both of these latter sections, $\mathrm{Li}$ is quoted first. The order of the entries, however, does not follow the Bencao at all.

We can also see quotations from $\mathrm{Li}$ making a new appearance in re-editions of older manuals on materia dietetica. For instance, Yamaoka Genrin’s 山岡元隣 (16311672) Shokumotsu waka honzō zoobo 食物和歌本草増補 (Augmented Materia Dietetica in Poetic Form), published in 1667, is for the most part merely a reissue of the contents of the Waka shokumotsu hon 20 o 和歌食物本草 (A Poetic Materia Dietetica)— an anonymous work published in 1630 — but its additional material is commentary derived from the Bencao. The original work, in two or three kan, introduced its

${ }^{23}$ This last one, titled Kösei hon₹ō kömoku 校正本草綱目 (Classified Materia Medica, Edited and Corrected), is known as the "Ekiken version," in reference to Kaibara Ekiken. This edition contains an additional table listing the entries with their Japanese names, which for the most part are identical with those given by Ekiken in his Yamato hoño (1708). However, the entries in the main text still follow Tashikihen, and the kunten glossing is of a level considered by some specialists to be incongruent with Ekiken's other scholarship. See Isono (op. cit.).

${ }^{24}$ Source: http://square.umin.ac.jp/mayanagi/materials/EdoBencaobook.html (accessed 1/1/2021). Note: working from the list provided on this page, in my calculation of the figures given above I have excluded encyclopedias and dictionaries (texts such as the Wamyō ruijushō 和名類聚抄). 
hon₹o-related knowledge on each of some 240 materials in the form of a dedicated sequence of Japanese waka 和歌 (31-syllable poems of a 5/7/5/7/7-syllable line structure). For example, the first verse of the sequence for the "boar" (inoshishi 猪) entry reads:

猪はひえにて手おひ百びやうのどくとしるべし血をうかす也 25

The boar, being cold, should be known to be toxic for a hundred diseases and wounds. It makes the blood float.

Such use of waka as a means for transmitting medical knowledge was already visible in Manase Dōsan's writings. Chinese poems were used by Dōsan for his students as mnemonic devices—a technique known as gejue 哥訣 in Chinese medical primers of the Ming period ${ }^{26}$ — but he also used waka. The Manase school, which had been using the Bencao since the beginning of the $17^{\text {th }}$ century, has been offered as one possible origin for the waka honzo genre. ${ }^{27}$ Yet it should be noted that, unlike the aforementioned Shokushō nödoku, the original Waka shokumotsu bon $\bar{o}^{0}$ did not make any reference to the Bencao.

In Yamaoka's work, before each poem sequence we find the name of the entry in Chinese as given in the Bencao, and a short extract from the Bencao's qiwei section. In the case of the boar entry, this extract simply previews the contents of the poem quoted above, stating that [the fierce boar's flesh] is "sweet, extremely cold, and has toxicity" (甘大寒有毒). Yamaoka then gives his own commentary on the Bencao's entry, explaining that $\mathrm{Li}$ distinguished between two kinds of boar, the “wild boar" 猪 and the "mountain boar" 山猪 (or rather "fierce boar" 豪猪, the "correct name" of the entry), but that the original Waka hon 20 s entry for "boar" had only referred to the mountain variety. At this point he accordingly added an entry on "wild boar," with two additional verses translating this new entry's Bencao extract into Japanese (waka) (Figure 1).

While integrating the contents of the Bencao, Yamaoka, who was a disciple of the poet and specialist in Japanese classics Kitamura Kigin 北村季吟 (1625-1705),

${ }^{25}$ Waka shokumotsu honzo $\overline{0}$ 和歌食物本草 (pub. 寛永 Kan'ei 7/1630), vol. 1. Available at: https: //dl.ndl.go.jp/info:ndlip/pid/1287084/3

${ }^{26}$ For more on this topic, see Angela Ki Che Leung, "Medical Instruction and Popularization in Ming-Qing China," Late Imperial China 24:1 (2003), pp. 130-152. See also Marta Hanson, "From under the Elbow to Pointing to the Palm: Chinese Metaphors for Learning Medicine by the Book (Fourth-Fourteenth Centuries)," The British Journal for the History of Science (BJHS) Themes 5 (2020), pp. 75-92.

${ }^{27}$ Regarding materia dietetica texts with explanations in the form of poems, see Hata Yuki 畑有紀, “Waka-keishiki de shirusareta shokumotsu honzō-sho no seiritsu ni tsuite” 和歌形式で記された 食物本草書の成立について, Kotoba to bunka 言葉と文化 14 (2013), pp. 37-56. Hata based her study on papers published by Ehara Ayako 江原絢子 and Sakurai Miyoko 桜井美代子 in Tōkyō kasei gakuin daigaku kiyo 東京家政学院大学紀要 32-34 (1992-1994), to which at time of publication I was unable to obtain access. Most of the texts discussed here have been collected as (annotated) facsimile editions in the series Shokumotsu honг̄o-bon taisei 食物本草本大成, 12 vols., gen. ed. Ueno Masuzō, ed. Yoshii Motoko 吉井始子 (Kyoto: Rinsen Shoten, 1980). 


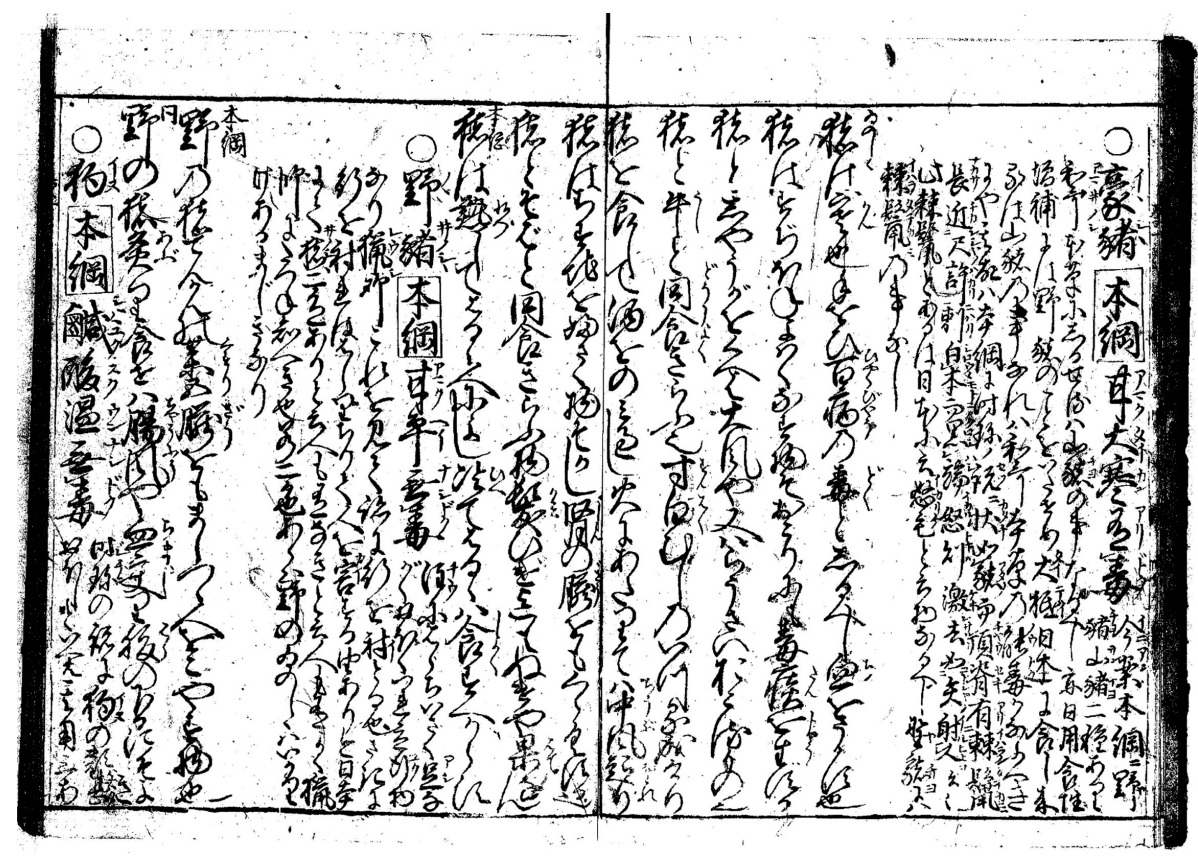

Figure 1. Shokumotsu waka honzō zōho 食物和歌本草増補. (NIJL). https://doi.org/10.20730/200005521 (image no. 7)

gave priority to the original order of the Waka honzō, which had been organized

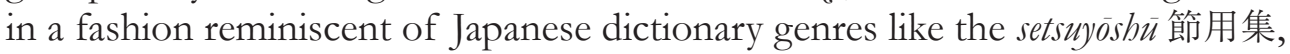
in that its poems were first indexed by initial syllable following the order of the iroha syllabary, then divided up among thematic categories: grains, plants, trees, fruits, beasts, birds, fish, insects. Thus, he deliberately ignored Li's organizational principles and the hierarchies Li had established between the entries of a group of species, allowing as a result the above inversion in the ordering of the two types of boars-in deference to a preexisting Japanese framework.

Similarly, Nagoya Gen'i 名古屋玄医 (1628-1696), founder of the “ancient recipes” (kohō 古方) school, in his Etsuho shokumotsu hon a o 閲甫食物本草 (Etsuho’s Materia Dietetica, 1669, printed in 1671), ${ }^{28}$ quotes heavily from the Bencao. This book in two volumes is written in Sino-Japanese (kanbun 漢文), and presents information on the properties of plants and animals. The Bencao and Li are regularly quoted on the topic of qiwei (quality and flavor) and on the applications and effects of various materials, but excerpts from Li's work do not always come first. The ten categories chosen by Gen'i are: grains (koku 款), vegetables ( $s a i$ 菜),

\footnotetext{
${ }^{28}$ Etsuho being one of Gen'i’s names. The work was published in Kyoto by Murakami Kanbei 村上勘兵衛, along with the aforementioned Noda one of the main publishers of the time.
} 
fungi (take 茸 and kin 菌, two categories), water herbs (suisō 水草, e.g. seaweeds), fruits ( $k a$ 菓), herbs ( $s \bar{o}$ 草), fish ( $g y o$ 魚), shells ( $k a i$ 介), and birds ( $k$ in 禽). The order of the entries does not follow Li's general plan, though there are groupings of entries that share similarities with the Bencao's implicit "families," such as for "beans" (tō or mame 豆) and for "chives and onions" (nira 韮 and negi 葱, respectively). This, however, may merely hearken back to other bon $\overline{o ̣}^{\circ}$ works, or even to the Wamyōshō, a source Gen'i has a marked tendency to cite, along with Razan's Tashikihen. Gen'i's commentaries deal mostly with the properties of the ingredients, and if he shows no hesitation in raising questions about what he reads in the Bencao, the critiques he voices are not trenchant. For example, in the work's first entry, which deals with uruchi 粳, or non-glutinous rice-as opposed to the glutinous variety, mochi 糯-Gen'i first quotes $\mathrm{Li}$ in stating that this rice is both sweet and bitter (kanku 甘苦), then goes on to make a brief note where he remarks that other texts speak only of its sweetness, adding that the rice one can taste today in Japan is not bitter. Rather than rejecting Li's statement, he wonders if the difference may "come from the quality of the soil" (是因二地気_然乎).

The Hōchū biyo wamyō hon $\bar{o} \overline{0}$ 店厨備用和名本草 (Materia Medica with Japanese Names to be Used in the Kitchen, 1684) of Mukai Genshō 向井元升 (or 玄松, 1609-1677) adopts quite a different stance. Mukai, a famous Confucian scholar and physician from Nagasaki, is well-known for his Kenkon bensetsu 乾坤并説 (Explanation of the Universe), a Japanese presentation with commentary of Sawano Chūan’s 沢野忠庵 (i.e. Christóvão Ferreira’s, 1580-1650) European astronomical and cosmological knowledge. ${ }^{29} \mathrm{He}$ is also known as an early receiver and transmitter of Western medicine and pharmacopeia, through his contacts with Dutch doctors in Nagasaki. ${ }^{30}$ In later life, Mukai established himself in Kyoto and interacted with other scholars, such as Kinoshita Jun'an 木下順庵 (1621-1699), a renowned master who penned one of the prefaces to this work, and Kaibara Ekiken. This Wamyo hon $\overline{0}$, written entirely in Japanese with katakana, was probably completed around 1671 (the date of Mukai's own preface), but was printed only in 1684. In his preliminary remarks, Mukai clearly positions the Bencao gangmu as the most up-to-date of Bencao works, and then announces that he will use it to discuss and correct (ben 弁) the names of the entries. In the first section out of thirteen,

\footnotetext{
${ }^{29}$ Hiraoka Ryūji 平岡隆二, “Kenkon bensetsu shoshahon no kenkyū” 『乾坤弁説』諸写本の研究, Nagasaki rekishi bunka bakubutsukan kenkyu kiyō 長崎歴史文化博物館研究紀要 1 (2006), pp. 5163; Idem, Nanban-kei uchüron no gententeki kenkyü 南蛮系宇宙論の原典的研究 (Fukuoka: Hana Shoin, 2013).

${ }^{30}$ On Mukai Genshō and his reception of Western knowledge, see Wolfgang Michel, "Shoki kōmō-ryū geka to jui Mukai Genshō ni tsuite” 初期紅毛流外科と儒医向井元升について, Nibon ishigaku zasshi 56:3 (2010), pp. 367-385; Idem, "On the emancipation of materia medica studies (honzoggaku) in early modern Japan", Proceedings of the 5 th International Symposium on the History of Indigenous Knowledge (2015), pp. 93-106.
} 
titled “investigating doubts" (shitsugi 質疑), Mukai reflects upon the degree of correspondence between the Japanese names given by Razan's Tashikiben or Shitagō's Wamyōshō and their paired Chinese characters. In doing so, he acknowledges the Bencao's innovations, noting for instance that, contrary to what had been current in the "old/former materia medica" (moto no bonzō 旧本草) Li had moved the $k i$ 葵 (Ch. kui) plant from the "vegetable" section to that of "damp herbs." ${ }^{31}$ In the 490 entries of his work, Mukai first gives the Japanese names from Wamyöshō and Tashikiben, when they exist, after which he introduces a "consideration of the Bencao" (bon₹ō wo kangauru ni 考本草), a section whose "Bencao" may refer to the bonzō literature in general, but which fairly frequently displays important similarities with Li's Bencao gangmu in particular. What is more, in other sections of the entries, Mukai sometimes quotes more explicitly from "Li Shizhen's Bencao gangmu," giving extensive translations into Japanese. He then adds his own observations, as well as additional advice (and warnings) about the consumption of the given ingredient. Regarding his selection and ordering of entries, despite his claim to use mainly "Dongyuan's Sbivu bencao" (東垣食物本草)— a work attributed to the Song-dynasty physician Li Gao 李杲 (Li Dongyuan 李東垣, 1180-1251)—what Mukai actually did was follow the structure of the Bencao gangmu, even keeping its narrower "Categories" (lei), such as "plains birds" (genkin 原禽), “water birds" (suikin 水禽), and “forest birds" (rinkin 林禽). In the specific case of birds, he had made changes to the order of the categories, moving the plains birds thus to the front, and omitting the group of "mountain birds" (sankin 山禽). For the remaining categories, however, he included all birds from the Bencao that he deemed edible, referring only to their Chinese names without trying to find Japanese equivalents, all while reintroducing entries from the Shimu bencao among these. On a few occasions, such as with the "snake and insect" section, Mukai did prefer the division used in Dongyuan's work, but in the particular case, this amounts only to a list of entries without any content. Mukai explains that, if these materials are included in Bencao books, it is because "of all that grows between Heaven and Earth, there is nothing foreigners do not eat, making no distinction between the toxic and the safe" (外国の人は天地の間に生ずるもの良毒をわかたず 一つとして食せざるはなし), which may, he says, make them ill and eventually lead them to their death. Japanese people, however, never eat insects or snakes, being blessed with “a naturally noble character” (天生の自然貴品にして) and an unrivalled diversity of products.

In other words, Mukai shows a rather clear understanding of Li's innovations in terms of structure and categories, and chose not only to follow them (or not), but to make them explicitly apparent. This may not come as a much of a surprise, given his systematic references to Tashikihen, but it is still a striking

\footnotetext{
${ }^{31}$ In fact, Mukai is here criticizing the identification of this plant with the aoi (afubi in traditional orthography), a Japanese plant written with the same 葵 character. He judges that the $k i$ 葵 should rather be identified with a wholly different plant, the fuki $i$ 蕗.
} 
difference compared to many of the previous shokumotsu bon₹o works introduced here above. At the least, it was certainly not a systematic feature in works published around the same time. Shimotsu Genchi's 下津元知 (dates unknown) Zukai hon $\overline{0}^{0}$ 図解本草 (Illustrated Explications of the Materia Medica, in 10 kan, completed in 1681, published in 1685), for example, opens with a portrait of $\mathrm{Li}$ Shizhen, which indicates the deference shown by the author to his predecessor. Yet the book itself follows the iroha order, and collates Li Shizhen's own findings with two other Chinese sources: Li Zhongli’s 李中立 Bencao yuanshi 本草原始 (1612), ${ }^{32}$ and the fairly recent Bencao dongquan 本草洞詮 by Shen Mu 沈穆 (1661). ${ }^{33}$ One of Shimotsu's goals was to distinguish between Chinese and Japanese plants, surmising that their therapeutic properties should be different. He makes clear reference to the Bencao gangmu, giving even the pages where one can find the corresponding entry, but he also relies on Japanese sources. He moreover makes important changes to the pictures, choosing not to use even the "new" Qianya version. Meanwhile, Arai Genkei’s 新井玄圭 Shokumotsu tekiyo o 食物摘要 (Chosen Extracts on Materia Dietetica, 1678, republished many times up to the end of the century with minor changes in title, e.g. Shokumotsu tekiyō taizen 大全, taisei 大成, etc.) shares as a work many traits in common with the Bencao gangmu. Written in kanbun with glossing points, it begins with a section on "waters," although with a slightly different order of entries, before moving on to grains, plants, and animals. In some sections, Arai chose to follow the order and subsections of the Bencao, but he did not do so systematically. He does distinguish between "scaly" and "scaleless" fish, for example. But in the bird section, plains birds and forest birds appear to be mixed up, and mountain birds are omitted, as they had been in Mukai's book. This new organization does not, however, seem to be arbitrary, but follows rather the lines of "covert families," which in this case are groupings based on the proximity of the birds' Japanese names. For instance, three different kinds of shigi, or sandpiper, are grouped together-the shigi 鵸, the botoshigi 秩鷄, and the ubashigi 竹雞—as are the tsuchigurebato 斑鳩 (oriental turtle dove), the aobato 青䳡 (green pigeon), and the iebato 鴿 (domestic pigeon). Moreover, Arai made an interesting choice regarding the identification of species: in the case of birds, after discussing 35 entries taken from the Bencao, he created a whole appendix where he listed in katakana the Japanese names of 32 species for

\footnotetext{
${ }^{32}$ On the reception of this work in Japan, see Mayanagi Makoto, "Chūgoku honzō to Nihon no juyō” 中国本草と日本の受容, in Nihonban Chügoku bon zō zuroku 日本版中国本草図録 9 (Chūō Kōronsha, 1993), pp. 218-229.

${ }^{33}$ On the Japanese reception of this work, see Mayanagi Makoto, "Honгo igen to tabako" 『本草彙言』と烟草, Tabako-shi kenkyūたばこ史研究 36 (1991), pp. 1480-1488. Mayanagi, in reflecting upon the manner in which the Chinese name for the tobacco plant was introduced, estimates the arrival of this Qing-period work in Japan at no earlier than 1680. According to Métailié, op. cit. (2006), pp. 47-48, its illustrations complement nicely those of the Bencao because of the former's focus on the various parts of the plants.
} 
which he considered there existed as yet no "correct name." Among these, notably, we find entries such as hibari or mozu, to which previous works had, in fact, assigned various Chinese characters, some of them even taken from the Bencao. In other words, rather than supplying a wrong identification for any of these Japanese entries, and thereby assigning it to the wrong place, Arai preferred instead to set these entries aside as matters for later elucidation. Although he may have used the term "appendix" (furoku 附録), reminiscent of Li's own fulu, Arai did not attempt to redistribute these entries under those of other species with certain identifiable traits in common. In other words, while Arai did integrate Li's method in part, the Bencao gangmu was not used here as an absolute model. Regarding the content of Arai's entries, it is subdivided into different parts, each clearly identified by a boxed header: kimi 気味 (quality and flavor), shokkin 食禁 (restrictions), shuji 主治 (main applications and effects), and, in some cases also sogi 䟽義 (commentary) and hōhō 方法 (recipes). Here also Arai departs from Li's model, as he favored the tradition already established by previous shokumotsu bonzō texts.

A work that goes further in its integration of Li's categories is Hitomi Hitsudai's 人見必大 Honchō shokkean 本朝食鑑 (Catalogue of the Food of Our Country, 1697). Hitsudai followed in the steps of Mukai and Arai, and reused a great part of the structure of Li's book. He included not only a section on waters, as Arai had, but also sections on fires and "earths," albeit with only a handful of entries each, though he did eventually expand them in order to incorporate further Japanese materials. After these sections, he followed Li's plan rather closely, keeping all the categories for the vegetables, three out of six for the fruits, and all the categories for the birds. He did also make some changes. For the grains, he placed the rices first and preferred, like Mukai, to group snakes and insects together in one volume-end category. He also merged the beasts and cattle into a single group, while leaving out the "wanderers and strange bipeds" (yuguai 寓怪, Jp. gükai). Finally, he doubled the number of categories for fish, by making a clearer distinction between freshwater and seawater fish, while also maintaining the presence or "absence" of scales as a discriminating criterion. ${ }^{34}$ Given that his aim was to compile a materia dietetica, Hitsudai logically left out sections on clothes, man, and even medicinal herbs. Nonetheless, by including fires and earths, and by expanding the fish categories-particularly in a way that capitalizes

\footnotetext{
${ }^{34}$ For a comparison between the Honchö shokkan and the Bencao gangmu in terms of contents and structure, see Li Li 李利 and Ehara Junko 江原絢子, “Honzō kōmoku to Honchō shokekan no bunrui ni miru shokubunka-teki na tokuchō”『本草綱目』と『本朝食鑑』の分類にみる食文化的 な特徵, Nihon chōri kagakukai-shi 日本調理科学会誌 40:3 (2007), pp. 193-201. See also Une Satsuki 畦五月, “Shokumotsu honzōo to Honchō shokkean no hikaku wo tōshita shokubunka no sōi to sore-zore no tokuchō ni tsuite shokuhin no seishitsu (kimi, kōnō) no chigai ni shiten wo atete” 『食物本草』 と『本朝食鑑』の比較を通した食文化の相違とそれぞれの特徵について食品の性質（気味、効能） の違いに視点をあてて, Nihon chōri kagakukai-shi 44:3 (2011), pp. 238-245.
} 
on Li's own design- he clearly demonstrates his intent to use the Bencao as a general model, and not merely as a source of information.

Thus, we can see that, although the Bencao came to be effectively the main source used by Japanese scholars for naming and describing plants and animals in the context of materia medica and dietetica, it was not until the late $17^{\text {th }}$ century that there appeared works explicitly embracing Li's categorization of the entries, along with his hierarchical scheme.

\section{The Bencao gangmu as an Inspiration for Illustrated Books}

Let us now turn to the other "line of reception" of the Bencao gangmu, i.e. the so-called "encyclopedic" works. Starting with the Tashikiben, these are works concerned for the most part with lexical issues-finding the correct names for things - and not with the pragmatic effects of medical or alimentary substances. The first and most well-known of such works that one reliably finds in lists of publications related to hon ro and natural history is probably the Kinmō ₹ui 訓蒙図彙 (Illustrated Vocabulary for Educating Children) complied by Nakamura Tekisai 中村惕斎 (1629-1702) and published in 1666..$^{35}$ Tekisai, a Neo-Confucian moralist who helped vulgarize Chinese classics into Japanese, wanted to give "children" new material for learning Chinese characters and their Japanese meanings, while also helping them associate each character with a single picture. Although the preface explains that he had in fact designed this vocabulary for one of his young relatives, actual "children" were not necessarily the only expected readers of the work. Indeed, lists of leishu類書 (Jp. ruisho, books arranged by categories) as far back as the Heian period, such as Shitagō's Wamyōshō, or his pupil Minamoto no Tamenori's 源為憲 (?-1011) Kuchizusami 口遊, had often presented themselves as guides for noble children. Tekisai can be said to have followed this topos, with a new twist: the "children" he had in mind, like many other contemporary authors of "educational" works in the vernacular, were those people not skilled enough in classical Chinese (or even in classical Japanese) to have direct access to sources of "higher" status.

In his preliminary remarks, Tekisai states that, for the Chinese characters, he used mainly Wang Qi's 王圻 Sancai tubui 三才図会 (Illustrated Collection of the Three Powers, 1607-9) and Xu Guangqi’s 徐光啓 Nongæheng quanshu 農政全集 (Complete Treatise on Agriculture, 1639), as well as "the illustrated explanations

${ }^{35}$ This work had many different editions over the years-in 1668, 1693, 1695, and in 1789. Each quite different from the others in terms of the contents, layouts, and illustrations it featured, these editions proved nonetheless able to coexist without replacing one another. See Christophe Marquet, "Instruire par l'image: encyclopédies et manuels illustrés pour enfants à l'époque d'Edo," in La pédagogie par l'image en France et au Japon, eds. M. Simon-Oikawa and A. Renonciat (Rennes: Presses universitaires de Rennes, 2009), pp. 84-90. See also Sugimoto Tsutomu 杉本つとむ, Jisho/jiten no kenkyuü 辞書・事典の研究 II, Sugimoto Tsutomu chosaku-shü 杉本 つとむ著作集 7 (Tokyo: Yasaka Shoten, 1999), pp. 233-276. 
of the specialists in materia medica" (shoke hon₹ō no zusetsu 諸家本草の図説). $\mathrm{He}$ also tells the reader that for the names of each of the entries, he had used the "correct name" (seimei 正名), and that, as sources for the Japanese names, among Japanese books he had used the Wamyöshō and the Tashikihen, as well as many dictionaries such as the Kagakushū 下学集 and the Setsuyoshy $\bar{u}$ 節用集 (both of the $15^{\text {th }}$ century). ${ }^{36}$ Given the time of publication, there is no doubt that Tekisai had access to the latest version of the Bencao gangmu, although Li's work is not cited per se. And indeed, many of Tekisai's illustrations for metals, minerals, plants, and animals had been taken directly from the Qianya edition of the Bencao. In some cases, such as for the "crocodile" (wani 鯨) or, even more strikingly, for the "horseshoe crab" (kabutogani 鱟), the "realistic" quality of his illustrations greatly exceeds that of the original. This may be partly explained by the shift in focus this "illustrated vocabulary" represents when compared to traditional bonæo books. As stressed by Roel Sterckx, bencao illustrations had mostly been conventional tools - "a commentarial extension of the text, or as yet another type of "nomenclature' that serves to circumscribe its properties"- rather than a means of clearly identifying the described materials as they were actually encountered in the field. ${ }^{37}$

In the case of Tekisai's illustrated vocabulary, the images are indeed "another type of nomenclature," except that the only texts associated with them are the Chinese characters and their Japanese names. In contrast to bonzo texts, where pictures might have been seen as secondary for readers with experience in the field - that is, for readers like the target audience of most of the works I have reviewed so far-the pictures in Tekisai's primers were no less important than the text itself, since they were required to create an equivalence between a vernacular word, a Chinese glyph, and an element of the surrounding world that, in many cases, already had its own standardized representation in visual materials such as paintings and picture books.

The illustrations in Tekisai's "Vocabulary" can thus be said to expand upon those in the Bencao, but as far as its organizational principles are concerned, the relationship between the Kinmō qui and the Bencao gangmu is not always clear. In the general structure of his work, Tekisai clearly follows the leish $u$ tradition, which also influenced Li Shizhen himself. The Kinmō zui thus distinguishes a first section on "heaven," followed by another on "Earth" (including geography and topography, as well as habitations), with the biggest part of the book being devoted to living things, starting with Man and his culture, before moving on to cattle and to beasts, to birds, to dragons and fish, to insects and shells, to rices

\footnotetext{
${ }^{36}$ On setsuyōshū in general, see Satō Takahiro 佐藤貴裕, Setsuyōshū to kinsei shuppan 節用集と近世 出版 (Osaka: Izumi Shoin, 2017).

${ }^{37}$ Sterckx, Roel, "The Limits of Illustration: Animalia and Pharmacopeia from Guo Pu to Bencao gangmu," Asian Medicine 4 (2008), pp. 357-394. On illustrations in bencao texts, see also by André-Georges Haudricourt and Georges Métailié, "De l'illustration botanique en Chine," Études chinoises 13:1-2 (1994), pp. 381-416.
} 
and grains, to vegetables, fruits, trees, and finally to flowers and herbs. In this regard, the Kinmō zui appears to be closer to Shitagō's Wamyöshö than to any other Chinese or Japanese leishu. This also accords well with the fact that Tekisai chose to “focus on Japanese names" (wamyō wo shu to su 和名を主とす), which made him favor a local tradition in terms of organization, e.g., by placing rice, and not hemp, at the beginning of the "grains" section.

Regarding the order of the entries within each section, we can detect competing logics at work, the "families" of the Bencao being only one among them. To take, for example, the case of birds, the Kinmo zui lists 77 separate entries, compared to the Bencao gangmu's 72 . But in fact, 6 of the 77 deal with various "parts" of birds and other "secondary" generic items, such as eggs, wings, or hatchlings, so there is not really much of a difference in number. Among the remaining 71 entries of the Kinmō zui, only 8 were absent from the Bencao, and Tekisai had found these in the Wamyōshö, e.g. the mo₹u 鵙 (bull-headed shrike). For their illustrations, he could turn to the Sancai tubui, but in many cases the "famous artists" he employed made their own drawings. This leaves 63 entries in common with the Bencao. The general order does not follow the four categories of birds devised by Li. Rather, it seems that Tekisai first listed birds with names in two characters, starting with the numinous and rare ones such as the hōo 鳳凰 (phoenix) and the kōsui 孔翠 (or kujaku 孔雀, peacock), followed by omu/inko 鴷武 (parrot), token/ hototogisu 杜鵑 (cuckoo), sekirei/ishitataki 鶄鴒 (wagtail), takuboku/teratsutsuki 啄木 (woodpecker), shōryō/sazaki 䳡㭺鳥 (wren), and henfuku/kawabori 蝙蝠 (bat), as well as rojilu鬳鶶 (cormorant), sökatsu/manazuru 鶬鴰 (white-naped crane), en'öloshidori

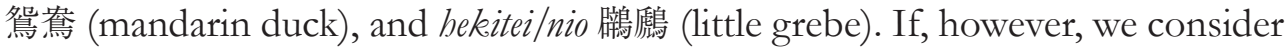
this group as a single section, we can say that, among its members, the four groups stipulated by $\mathrm{Li}$ are more or less preserved, albeit in reverse order: mountain, forest, plains, water.

Following this, we find birds named by one unique character, beginning with kaku/tsuru 鶴 (crane) and kan/ötori 鸛 (stork), which were the first pair of "water birds" in the Bencao. Then comes a cohesive group of birds of prey (hawks and eagles, etc.), in an order very close to the Bencao's. Tekisai has even given entries of their own to birds that in the Bencao had only been "appended" under the entries of others, such as en/tobi 蔦 (kite) and shun/hayabusa 隼 (falcon). These birds of prey are then followed in turn by what Li had categorized as "water birds" (ducks, etc.), "forest birds" (crows, etc.), and "plains birds." As before, in most cases the order preserves the Bencao's "families." Even when—as in the cases of kyö/fukurö稇 (owl) or ro/sagi 鷺 (egret)—an “intruder” seems to break the line, it is usually a matter of visual presentation on the page, in order to, e.g., put bu/kamo 自 (wild duck) together with gaku/abiro 驚 (house duck), allowing the two ducks to face each other. The birds section as a whole ends with a furok $u$ 附録 (appendix), in which the Bencao's order is not really preserved, with groupings there that seem to rely more on the characters themselves (it begins, for instance, with a whole series of roosters whose names contain the character ke $i$ 鶏). Thus, 
although Li's work clearly influenced Tekisai, and while the general idea of a "family" of species is, if anything, made here even more visible through the use of pictures, the systematic preservation of Li's design per se was not one of the compiler's priorities.

Tekisai's Kinmō zui was published amidst a first, timid growth in the publication of such illustrated texts, probably stimulated by the same group of Ming works, as well as by other commentaries of classical texts with pictures. For instance, in 1667, the publisher Ōwada Kyūzaemon 大和田九左衛門 produced a new, annotated version of the Sangoku söden on'yō kankatsu Hoki naiden kin'u gyokuto shü 三国相伝陰陽輨轄笽筫内伝金烏玉兔集 (Book of the Golden Crow and the Jade Hare, Secret and Exposed, of the Round Vessel and the Square Vessel, the Wheel and the Wedge, the Yin and the Yang, Transmitted Through the Three Countries).$^{38}$ Often simply abbreviated as the Hoki, this was an apocryphal treatise on hemerology and calendar divination attributed to Abe no Seimei 安倍晴明 (921-1005), to which Ōwada had added a further volume containing pictures and explanations. Considered at the time to be one of the founding classics in the field of divination, the work itself had been in print already from the very beginning of the $17^{\text {th }}$ century, with editions published both in moveable type $(1612,1627)$ and in woodblock (1628). This new text by Ōwada, however, was the first annotated and illustrated edition of the work. The publisher was very much conscious of this uniqueness, stating, in an afterword, that he had "added a separate volume at the end with pictures," this being "a direct means of making [the text] clearer" (附巻尾於図説。釈其事、解其義。夫能直而明之。). And indeed, in this additional volume, Ōwada included pictures and tables corresponding to many of the text's keywords. More than this, for most of the hundred illustrations the book contains, he clearly specifies even the original sources of the pictures. Among them, 17 had been taken from the Qianya edition of the Bencao gangmu, 13 from the Sancai tubui, 12 from the Wujingtu 五経図 (Pictures of the Five Classics, 1614)—another Ming work, 32 from Mao Yuanyi's 茅元儀 Wubei 2 hi 武備志 (Treatise on Military Preparations, 1621), ${ }^{39} 10$ from “a certain book" (aru sho 或書), and the remaining 16 from various other Chinese texts. Illustrations from the Bencao are concentrated in two main entries, both of which deal with a particular series of items that appears in the main text: the “five grains" (gokoku 五穀) and the “seven rarities" or “seven treasures" (shitchin 七珍/shippō 七宝). The first group is a ubiquitous series, with many variants differing in both contents and ordering. In this specific case, the "grains" are: kibi 棣 (proso millet), mame 菽 (soy), asa 麻 (hemp),

\footnotetext{
${ }^{38}$ On divination texts in Edo Japan, see Matthias Hayek, "From Esoteric Tools to Handbooks 'For Beginners': Printed Divination Manuals from the Seventeenth Century to the Beginning of the Eighteenth Century," in Listen, Copy, Read (op. cit.), pp. 46, 288-318; Idem, "Edo jidai no 'ura' wo kaimamiru” 江戸時代の『占』を垣間見る, Shomotsugaku 書物学 12 (2018), pp. 2-8.

${ }^{39}$ A domestic edition, with glossing points by the Confucian scholar Ukai Sekisai 鵜飼石斎 (1615-1664), was published in 1664.
} 


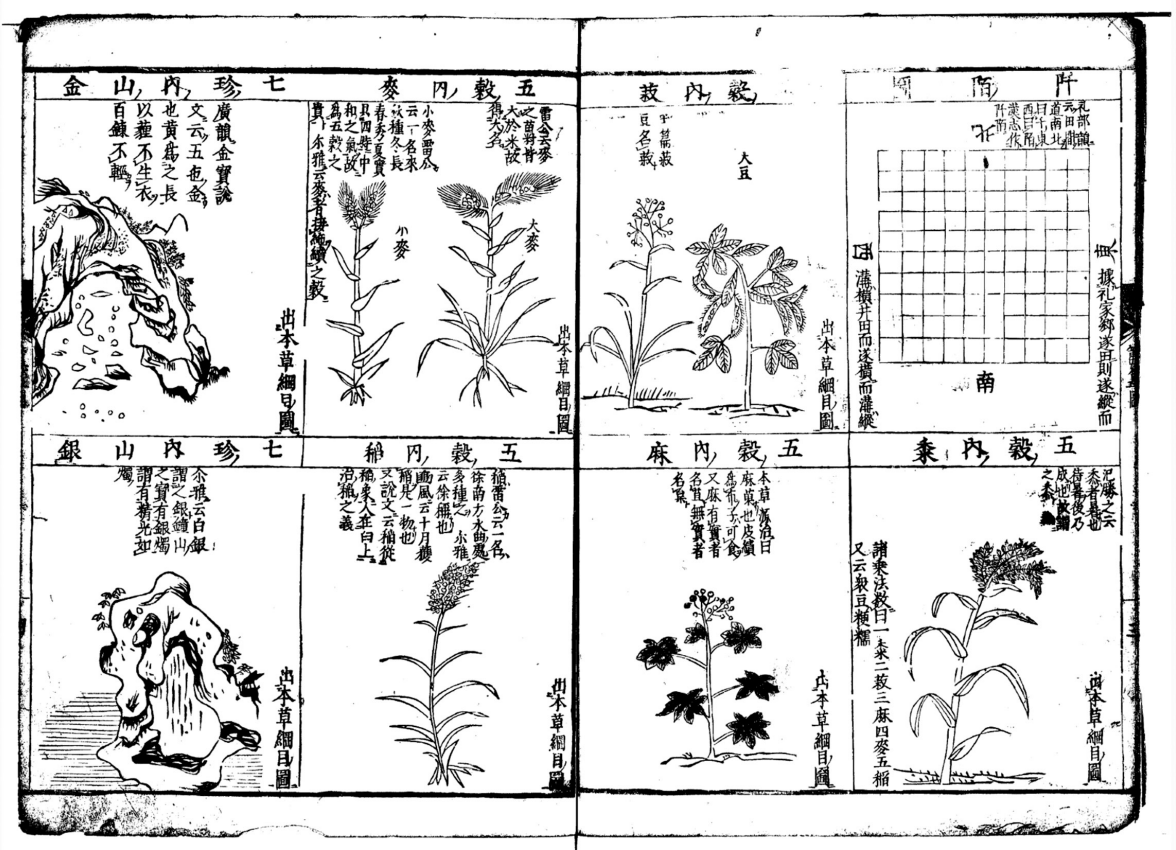

Figure 2. The five grains (gokoku 五穀). Sangoku söden on'yo kankatsu Hoki naiden kin'u gyokuto shü zukai 三国相伝陰陽輨轄笽篮内伝金烏玉免集図解. (NIJL).

https://doi.org/10.20730/200005702 (image no. 6)

mugi 麦 (wheat), and ine 稲 (rice). For each of these, the text gives a picture and a short quotation (Figure 2).

Although the pictures all come from the Bencao gangmu, the quotations themselves do not. In most cases, they were taken from Li Zhongli's Bencao yuanshi. What is more, the order of the five grains here is different from that put forth by Li Shizhen who, quoting the Sunven 素問 (ancient medical text of the Qin-Han period), put hemp first, followed by wheat, then two sorts of millet ( $j i$ 稷 and $s b u$ 乘), and finally soy. In fact, the order in Ōwada's work comes from a particular Buddhist treatise, one actually quoted in one of the pictures: the Zhucheng fashu 諸乗法数 (Ritual Numbers of the Different Vehicles), compiled by the monk Xingshen 行深. ${ }^{40}$ The seven treasures, too, form a Buddhist group— the saptaranacomposed of kin 金 (gold), gin 銀 (silver), ruri 瑠璃 (“lapis lazuli"), hari 玻璃 (quartz or crystal), shako 硨磲 (giant clam), meno 瑪瑙 (agate), and shinju 真珠 (pearl). All of these are included in the Bencao, but not as group, since they belong to a number of different categories, ranging from "shells" (shako) to "minerals" (gold). In this case, the quotations given in the pictures are from the Fanyi mingyi ji 翻訳名義集 (Collection of Translated Names), a Song-period Buddhist text

\footnotetext{
${ }^{40} \mathrm{~A}$ domestic re-edition of this early Ming work was published in 1500.
} 


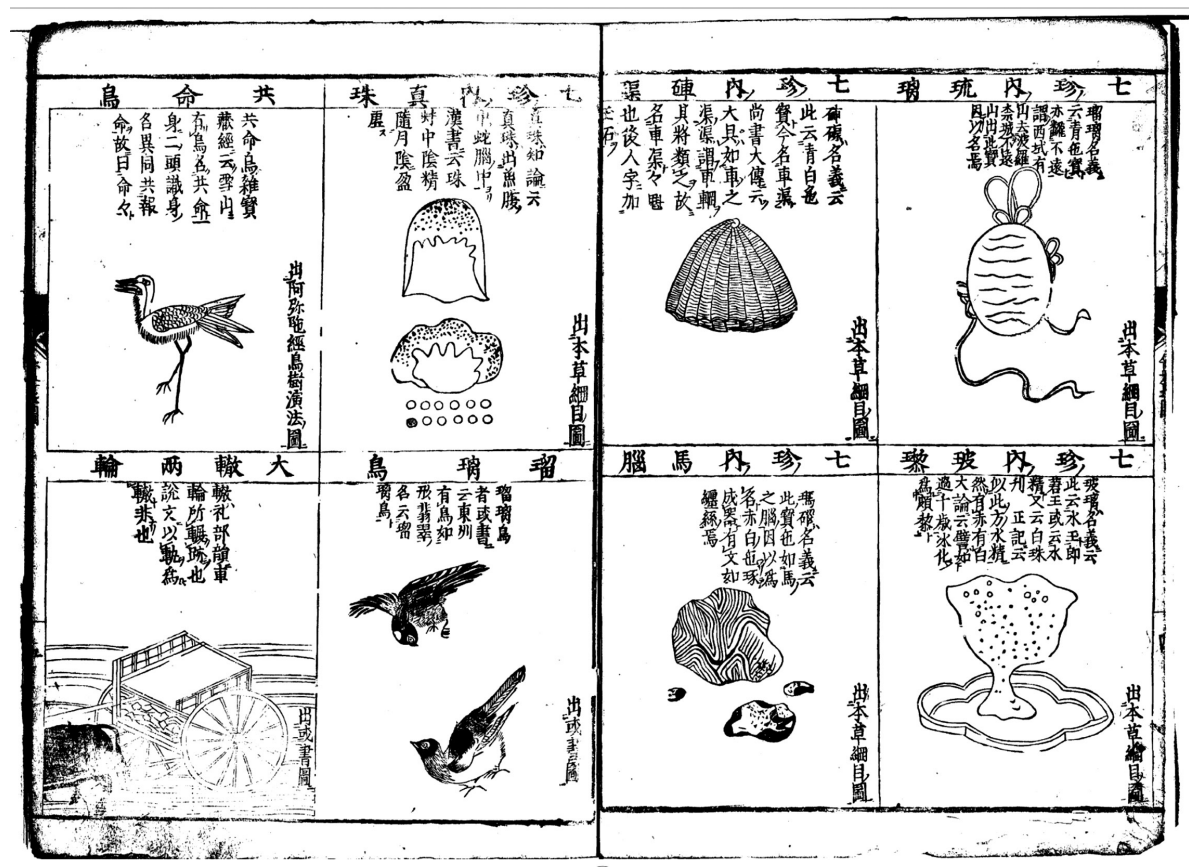

Figure 3. The seven treasures (shitchin 七珍). Sangoku sōden on'yō kankatsu Hoki naiden kin'u gyokuto shū zukai 三国相伝陰陽輨轄笽笽内伝金烏玉兔集図解. (NIJL).

https://doi.org/10.20730/200005702 (image no. 7)

reprinted in Japan in 1628. In other words, the editor of this new version of the Hoki used the 1640 edition of Li's Bencao above all as a practical source for pictures needed to represent Buddhist notions, an approach that can clearly be linked to both the "lexicographic" and the "encyclopedic" perspectives we see in the Kinmō zui, though Ōwada's work itself displays no similar regard for Li's design or his findings (Figure 3). ${ }^{41}$

From 1684 onwards, this trend of illustrated commentaries accelerated, with the last part of the $17^{\text {th }}$ century seeing the publication of ever greater numbers of illustrated catalogues specializing in different topics, from clothes, to people, to weapons and armor, etc., many of them bearing the phrase kinmó zui in their titles. ${ }^{42}$ Being "topic-oriented," however, most of them lack the broader, "encyclopedic" view of the original.

One notable exception would be the Nanji kunmō zui 難字訓蒙図彙 (Illustrated Vocabulary for the Education of Children, with Characters Difficult [to Read]).

\footnotetext{
${ }^{41}$ Incidentally, a similar text, with the new title Hoki genkai taizen 笽笽諺解大全 (Complete Compilation of the Hoki, Explained in the Vernacular), was published in 1682 by Nakano Sōzaemon 中野宗左衛門, but uses the same pictures without even mentioning their origin.

${ }^{42}$ Most of these have been collected in the series Kinmō zui shüsei 訓蒙図彙集成, 8 vols., ed. Asakura Haruhiko 朝倉治彦 (Tokyo: Ōzora-sha, 1998).
} 
This book, in five kan, published in 1687, is based on an earlier dictionary by Nagai Johei 永井如瓶 (1661-1731), a poet from Osaka. This source text, Jigen benmōshō 雨言便蒙抄 (Collection with Easy Words to Help Children), published in 1682, had three volumes: one for the "head" 首, one for the "navel" 臍, and one for the “feet" 足. Entries in the Jigen benmōshō were distributed over 12 categories: kenkon 乾坤 (Heaven and Earth), jiko 時候 (time and weather), jing $i$ 神祇 (spirits and gods), jinrin 人倫 (people), kikei 気形 (“forms of the $q \imath$ " = animals), shitai 支体 (body parts), sōmoku 草木 (herbs and trees), ishoku 衣食 (clothes and food), kizai 器財 (vessels and tools), kyotaku 居宅 (habitations), saishiki 彩色 (colors), and gengo 言語 (language). As the author Nagai himself explains in his preliminary note, this is a variation on the "three powers" system, projected on a human body, with these thematic categories representing the twelve months of the year. The categories are not original, and closely resemble those of the Setsuyoshui. what makes Nagai's work unique is the way he supplies different contents for the same topics across the different volumes. The first volume "gathers characters and words commonly used in the world," while the second focuses on explaining the meaning and origins of "difficult characters" (nanji 難字). The last volume then deals with "alternative names" (imyo 異名) and reflects on "precedents" (koji 故事). Such, at least, is the theory behind the organization, though it is not applied equally to all the various sections.

The 1687 reedition as the Namji kunmō zui, however, while keeping this general structure, transformed Nagai's opening remarks into a full preface, and added a line indicating that new pictures had been introduced throughout. Nor are these pictures—by the famous artist Hishikawa Moronobu 菱川師宣 (d. 1694)—the only changes made to the contents of the original. The editor has indeed moved whole sections of text around between the volumes, making the original differences between the "head," "navel," and "feet" volumes almost indistinguishable. He has also added numerous entries in the animal sections, with 34 new entries for birds alone. Many of these new entries, moreover, are absent from the Kinmō zui, but can be found in either the Bencao gangmu or the Sancai tubui. More than half of them correspond to what Li called mountain birds, though they are not listed in the same order, and among them, several "fabulous" birds which had lacked independent entries in the Bencao, such as the ran 鸞 (Ch. luan), or entirely new ones, such as the ishikuidori 石食鳥 (cassowary), are featured prominently—though without any explicative text (Figure 4).

These "new" entries were then finally themselves included in the Zōho tōsho Kinmō zui 増補頭書訓蒙図彙 (Augmented Version, with Head-notes, of the Kinmo zui) published in 1695, as a sort of extension of the work's earlier "appendix" to the birds section—although by this time, mention of the "appendix" itself had disappeared. 


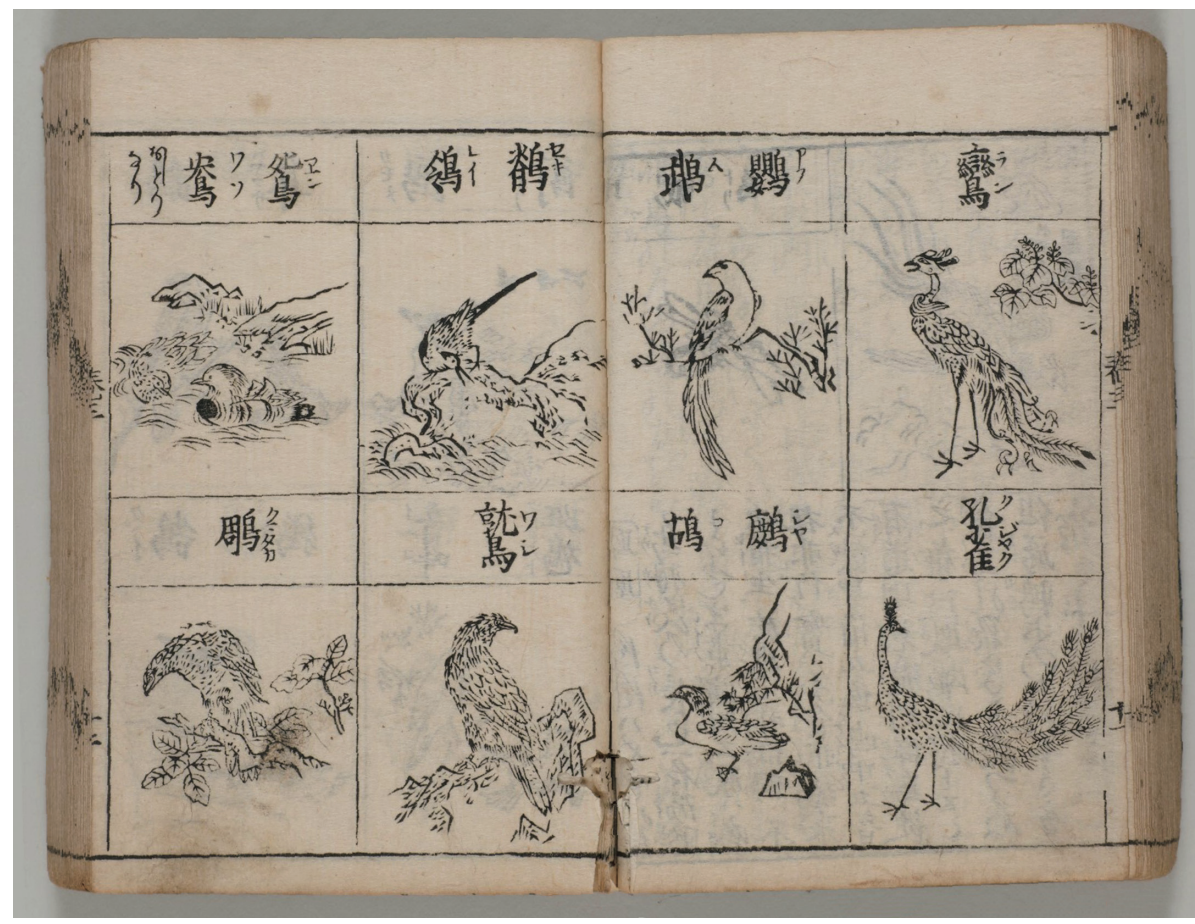

Figure 4. Nanji kinmō zui 難字訓蒙圖彙. (NIJL, Ukai Bunko 鵜飼文庫). https://doi.org/10.20730/200019308 (image no. 57)

\section{Conclusion}

Through this brief and partial survey of $17^{\text {th }}$-century hon₹ō and encyclopedic literature, my goal was to reflect upon the idea, still frequently put forth when presenting the developments of naturalistic knowledge in Japan, that $\mathrm{Li}$ Shizhen's Bencao gangmu was widely perceived already at the time as an authoritative work, one from which only $18^{\text {th }}$-century scholars such as Kaibara Ekiken finally "broke free." At the end of our journey here, the situation appears more nuanced. Li's Classified Materia Medica was indeed a ubiquitous reference in Japanese bon₹o works published after its introduction in the country. It was regularly quoted in books in Chinese, and translated or paraphrased in books in Japanese. However, for almost seventy years, these quotations and references were limited in their purpose to mere identification of the names of materials and their effects. This is not in itself surprising, for at least two reasons. Firstly, Razan's Tashikiben, which provided a point of connection between Li's work and the oldest available local authority, the Wamyōshō, was, as Marcon puts it, a "book of names," ${ }^{43}$ and

\footnotetext{
${ }^{43}$ Marcon (op. cit.), p. 67.
} 
it may have led to an emphasis on the zhengming aspect of the Bencao. Secondly, both materia medica and materia dietetica were mainly concerned with the toxicity and potency of the various materials, and in this regard, proper identification was of course especially crucial. Yet the originality of Li's work resides not only in its lexicographical aspects, but also in its broad rethinking of the categories themselves - and of the hierarchy between entries-as an expression of the Neo-Confucian "investigation of things." As far as can be gleaned from printed books, this aspect seems to have eluded Japanese hon₹ō specialists, and "encyclopedists," for the major part of a century, Razan being an early exception. Instead, they tended to keep to older classifications, whether from other, older bencao books or from older local encyclopedias and dictionaries. Again, there are reasons for such a situation, as above all books in the vernacular were designed precisely not to be exhaustive summa, but to serve rather as pragmatic tools for learning, or for quickly looking up the properties of a given ingredient. What is more, at the time of its introduction, the relative novelty of the Bencao may have been itself a disadvantage, in a context where older texts were generally regarded as having the greater authority. Even authors like Mukai, who showed a deeper interest in the classificatory innovations of the Bencao gangmu, did not follow them "blindly," and indeed preferred to put forth a (supposedly) older work, the Shiwn bencao. Mukai often relied on the knowledge he gathered from foreigners in Nagasaki to offer different points of view, and in some cases, he did not hesitate to do so even thirty years before Ekiken's Yamato hon₹ō. Meanwhile, though illustrated books did make use of Li's work, this was mostly for its pictures, and not for its text or for its general structure, although we can sometimes see Li's logic nonetheless partially piercing through in Tekisai's Kinmō zui. All in all, it seems to me that the $17^{\text {th }}$ century was a period rather of the Bencao being "digested bit by bit," leading eventually to a more general integration of Li's worldview at the very end of the 1690's with works like the Honcho shokkan. These works, which finally established the Bencao gangmu as a "classic" to be followed, paved the way for what may have been the true juncture point of the "medicinal" (naturalistic) and “encyclopedic" lines of Japanese scholarship: Terajima Ryōan's 寺島良安 Wakan sansai zue 和漢三才図会 (Illustrated Compendium of the Three Powers of China and Japan), published around 1715. Further research should thus focus on the reception of the Bencao gangmu in the first part of the $18^{\text {th }}$ century, seeing the period not so much as one of emancipation from the Bencao model, but rather as one in which the work's more theoretical and organizational aspects were discussed, reused, or discarded—and to what ends. 


\section{Comparison between the Bird Sections of the Bencao gangmu, the Kinmo zui, and the Nanji kinmo zui}

(1) Background Colors: blue $=$ water birds, pink $=$ plains birds, green $=$ forest birds, gray $=$ mountain birds, white $=$ birds not found in the Bencao gangmu. (2) Script: red type $=$ changes in the order of entries. (3) Signs: \# = entries annexed to the fulu section in the Bencao gangmu, $\$=$ names mentioned in the shiming or jijie sections as alternative names or related kinds. Note: English translations of the Bencao gangmu follow Paul U. Unschuld, trans., Ben Cao Gang Mu, Volume IX: Fowls, Domestic and Wild Animals, Human Substances (Oakland: University of California Press, 2021).

Bencao ganmu

本草綱目

\section{Water Birds}

鶴 he, red crowned crane

鸛 guan, white stork

鶬雞 cang $j i$, gray crane

陽烏 yang niao, yang bird

鵚鶖 tu qiu, lesser adjudant

鳥蒙䮵 meng tong, meng tong

鵜鴣 ti hu, pelican

玨 $e$, oriental swan goose

鴈 yan, wild goose

鵠 $h u$, whooper swan

铇 bao, great bustard

䉆 $m u$, domestic duck

兒 $f u$, wild duck

鸊源鳥 pi ti, grebe

鴛驀 yuan yang, mandarin duck

袧鵣 $x i$ chi, xi chi

鵁鶄 jiao jing, Chinese squacco heron

鷺 $l u$, little egret

鷗 ou, common gull

罵鳿 ₹ $\not h u$ yu, ₹ $b u y u$

膚鷀 lu ci, common cormorant
Kinmō zui

訓蒙図彙

鳳凰 $h \bar{o} \bar{o}$, phoenix

孔翠 kōsui (kujaku 孔雀), peacock

鷃武鳥 ómu/eibu, parrot

杜鵑 token (bototogisu), cuckoo

鶄鴒 sekirei (ishitataki), wagtail

啄木 takuboku (teratsutsuki), woodpecker

䳡袀 shöryō (sazaki), wren

\$蝙蝠 henfuku (kawabori), bat

虜鶶 roji (u/shimatsudori), cormorant

鶬鴰 sōkatsu (manazuru), white-napped crane

鴐䳡 en'ō (oshidori), mandarin duck

辟鳥鵤 hekitei (nio), little grebe

鶴 kaku (tsuru), crane

鸛 kean (ōtori), stork

鷹 yō/o (taka), hawk

鷲 shü (washi), eagle

$\$$ 焉 en (tobi), kite

\$集 kyō (fukuro), owl

\$鷂 yō (bashitaka), sparrowhawk

\$隼 shun (bayabusa), falcon

鴻 kōo (hishikui), bean goose

鵠 kōo (kugui), swan
Nanji kinmō qui

難字訓蒙図彙

First volume (jökan 上巻)

鶴 tsuru

鴈・陽鳥 kan, yochō

鶯 uguisu

鵎 niwatori

燕 tsubame

鵤 hototogisu

Third volume (maki no san 巻之三)

比翼鳥 biyokudori, single-winged bird

\begin{tabular}{|c|}
\hline 鳳凰 hōō \\
\hline \$鸞 ran \\
\hline 孔雀 kujaku \\
\hline 溳鳥武鳥 òmu \\
\hline 麃鴣 shako \\
\hline 鷕鴒 sekirei \\
\hline 熟 washi \\
\hline 鴐驀 en’o (oshidori) \\
\hline 鵰 kumataka \\
\hline 鷂 hasbitaka 隼 hayabusa \\
\hline 鵠 kugui 鵜 $u$ \\
\hline 鴎 kamome 徨 chidori \\
\hline 白鸘 hakkan \\
\hline
\end{tabular}




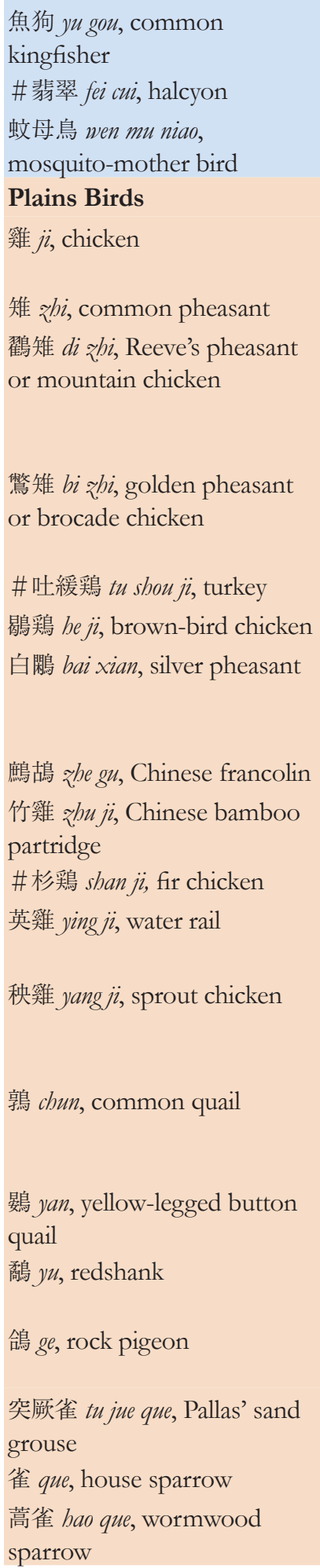

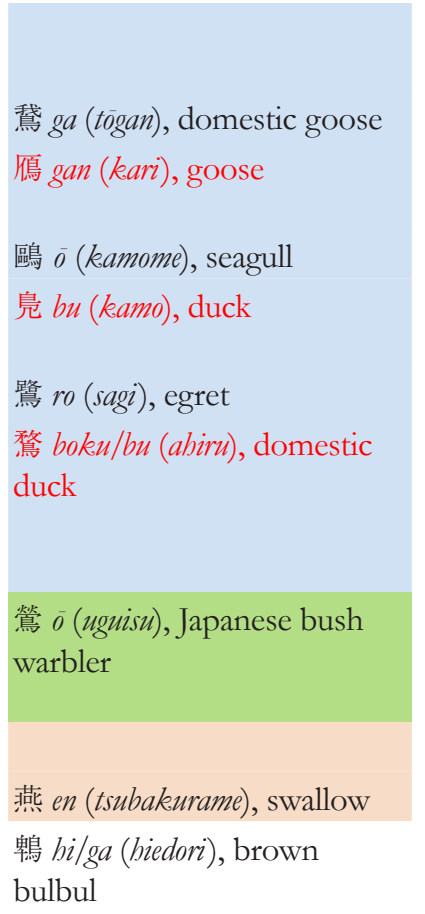

鵲 shaku (kasasagi), magpie
鴉 a (karasu), large-billed crow
烏 $u$ (karasu), crow
鳩 kyū/ku (bato), pigeon

鴿 kō (iebato), domestic pigeon

鵤 itsu (shigi), sandpiper or snipe

鶉 jun (u₹ura), quail

鵣 tō (tsugumi), thrush

鵙 keeki (mo₹u), butcher bird

雀 jaku (su₹ume), sparrow

鵊 $f u$ (shitoku), bunting

鴗 ryū (soi), kingfisher

\section{鴆沜 toshiyorikoi}

䲴 chin

\section{梟 fukurō}

鵤 karuga, Japanese grosbeak 矮鶏 $c h a b o$

黄雞 Kashiwa

雀䳕 $t s u$

\section{兄鶏 konori, Eurasian}

sparrowhawk

雀戡 essai, male Japanese sparrowhawk 鸇 sashiba, grey-faced buzzard

\section{木菟 mimizuku}

鵺 nue

姑獲鳥 ubume

水札 keri, grey-headed

lapwing 鵣 tsugumi, thrush

鸛鵒 biyodori

鶬 hibari

\section{烈 keratsutsuki}

弱 biwa, siskin

鸒 $u s o$, bullfinch

山雀 yamakara, varied tit; 鵙 mozu, bull-headed shrike, 百舌鳥 mo₹u

瞗 kuina 杜鵑 hototogisu

四十柄 shijükara, Japanese tit; 喚子鳥 yobukodori

剥豚鳥 teratsutsuki 䲴 höjiro meadow bunting

翠雀 ruri 鴰 bigara, coal tit

卵 tamago 轭 sueri

石食鳥 ishikuidori (cassowary) 
巧婦鳥 qiao fu niao, Eurasian wren, or 䳡鵸 jiao liao, jiao liao 燕 yan, swallow

石燕 shiyan, stone swallow

伏翼 $f u y i$, bat

䴎鼠 lei shu, complex-toothed flying squirrel

寒號蟲 han hao chong, complex-toothed flying squirrel

\section{Forest Birds}

斑鳩 banjiu, pigeon

青倠 qing zhui, greenish pigeon

隝鳩 shi jiu, common cuckoo 桑鳫 sang hu, Chinese grosbeak

伯勞 bo lao, shrike

鸛鵒 qu yu, crested mynah

百舌 bai she, one hundred tongues

練鵲 lian que, paradise

fly-catcher

䉆 ying, oriole

啄木鳥 zhou mu niao, great spotted woodpecker

慈烏ci wu, jackdaw

烏鴉 wu ya, large-beaked crow

鵲 que, Eurasian magpie

山鵲 shan que, red-beaked blue magpie

鶻嘲 bu chao, hoopoe

杜鵑 du juan, lesser cuckoo

䴗武鳥 ying $w u$, parrot

\#秦吉子 qin ji liao

\#鳥鳳 niao feng

\section{鶚 kaku (misago), osprey}

雞 kei (niwatori), chicken

雉 $c h i(k i j i)$, pheasant

卵 ran (tamago), egg

雛 $s \bar{u}$ (bina), chick

羽 $u(b a)$, feather

翼 yoku (tsubasa), wing

嘴 shi (kuchibashi), beak

尾 bi (o), tail

\section{Appendix (furoku 附録)}

\$鶤雞 konkei (tömaru), gamecock

矮雞 waikei (chabo), Japanese bantam

錦雞 kinkei, golden pheasant 綬雞 jukei, tragopan; horned pheasant

\$山雞 (鶷雉) sankei (yamadori), long-tailed pheasant

\$火雞 (䮀鳥) kakei, cassowary 竹雞 chikukei (yamashigi), woodcock

秩雞 ōkei/yōkei (kuina), water rail

青鳩 seikyū (yamabato), green pigeon

鳴鳩 shikyū (kakkoōdōri), common cuckoo

\$角鴟 kakushi (tsuku), eagle owl

\$怪鴟 kaishi (yotaka), grey nightjar

\$㿝鵰 sōshū (kumataka), black butcherbird 


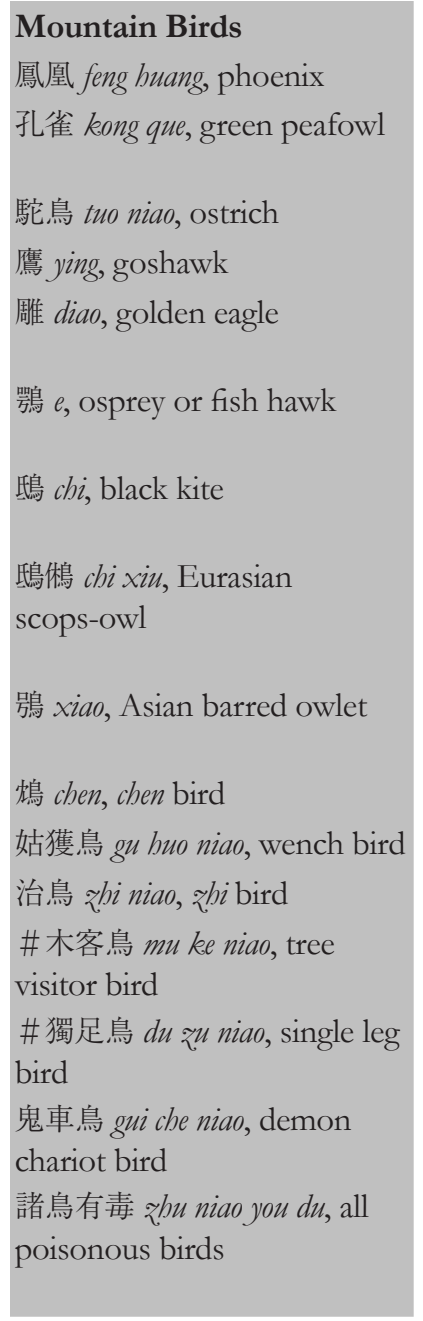

\$紅鶴 kōkaku (tsuki), flamingo 白闖 hakkan, silver pheasant 烏鳳 $u$ hö (onagatori), Japanese paradise flycatcher

雲雀 unjaku (bibari), skylark 翠雀 suishaku (ruri), bluebird 画眉 gabi (bohojiro), Chinese huamei

\$葻嘴 rōshi (mamedori), hawfinch

山鵲 sanshaku, red-billed blue magpie

練鵲 renjaku, Japanese

waxwing ( ${ }^{*}$ not to be mistaken with the 連鵲 renjak.u)

鵁鶄 kōsei (goisagi), black-crowned night heron

鸛鵒 kuyoku, mynah bird 